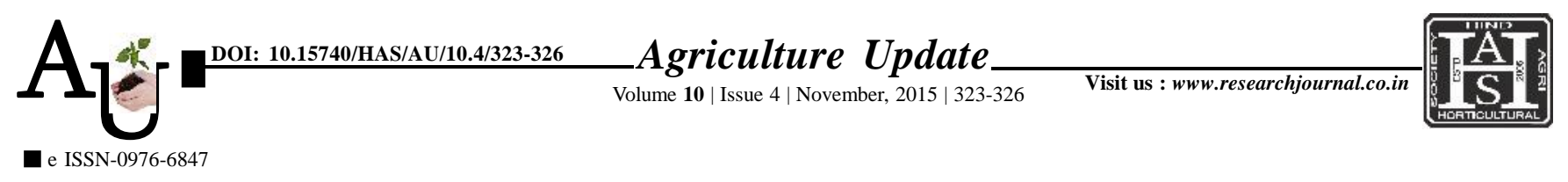

\title{
Research Article: Boosting of pulse productivity through front line demonstration to improve the nutritional security of the farmers of Tripura
}

\section{MANDIRA CHAKRABORTI}

Article Chronicle: Received : 24.09.2015;

Revised : 03.10.2015; Accepted : 17.10.2015

\section{KEY WoRds:}

Front line demonstration, Pulses, South Tripura, Economics

Author for correspondence :

\section{MANDIRA}

CHAKRABOTRI

Krishi Vigyan Kendra, BC Manu, SOUTH TRIPURA

Email: cmandira1@ rediffmail.com
SUMMARY : Increasing productivity of crops ensure the food and nutritional security of the farmers which depends upon the soil fertility and productivity. Pulses can play a vital role in nutritional requirement and also increases the fertility status of the soil. In Tripura state, pulses are grown in very small area using mostly local varieties. Area under different pulses crop in Tripura is 5361 ha (2008-09) and production is $3496 \mathrm{MT}$. In general, farmers do not follow scientific package of practices due to which the productivity of pulses is only $600 \mathrm{~kg} / \mathrm{ha}$. With a view to increase the productivity level of pulses and nutritional security of the farmers family of South Tripura, 60 front line demonstration (FLD) on three pulse crops like lentil, Moong and Arhar was undertaken during Kharif and Rabi season of 2008-10 by Krishi Vigyan Kendra of South Tripura. The objective of the FLD on pulses was to demonstrate the potential of improved varieties and technologies to the farmers. Five villages were identified through PRA method. Awareness programme and training on scientific cultivation practices of lentil, Moong and Arhar were conducted before starting the FLD. Besides imparting training, printed leaflets on pulses were distributed among the farmers for their ready reference. Field day programme was also conducted in the farmer's field in standing crop. Altogether 12 ha area of pulses was covered under this programme. Improved variety of lentil (WBL-58), Moong (HUM-16) and Arhar (Narendra-1) were demonstrated for obtaining higher yield as compared to local varieties and traditional method of cultivation. Yield percentage increased from 21.43 to 40 per cent. Farmers earned upto Rs. 43,000/- by selling pulses crops in the local market. The enhanced production through the demonstration of improved technologies with improved varieties in pulses helping farmers for its adoption for achieving the nutritional security (protein) of their family.

How to cite this article : Chakraborti, Mandira (2015). Boosting of pulse productivity through front line demonstration to improve the nutritional security of the farmers of Tripura. Agric. Update, 10(4): 323-326. 